\title{
POR UMA CORPOREIDADE DAS IMAGENS: ALGUMAS REFLEXÕES (IN)DISCIPLINADAS SOBRE CORPO, GÊNEROE SAÚDE NO CINEMA MOÇAMBICANO
}

\author{
FOR A CORPOREITY OF THE IMAGES: SOME (IN)DISCIPLINED \\ REFLECTIONS ABOUT THE BODY, GENDER, AND HEALTH IN THE \\ MOZAMBICAN CINEMA
}

Esmael Alves de Oliveira

Simone Becker

\begin{abstract}
RESUMO: Através desse artigo, uma vez mais, o duo autoral produz espaço para a proliferaçăo de diálogos afeitos e afetados pelos interesses antropológicos. Agora, as trocas tocam a importância de pensar temas caros ao campo antropológico, tais como corpo, gênero e saúde, à luz do cinema moçambicano. Para isso, tomamos como foco de nossa análise o curta Mâe dos Netos. O objetivo, a partir de uma escrita ensaística, foi o buscar perceber de que modo a narrativa cinematográfica moçambicana contemporânea significa a pandemia do HIV-Aids. Nossa hipótese principal foi a de que o cinema de Moçambique ao voltar-se para a temática de corpos atravessados pela experiência do HIV-Aids constrói uma dinâmica e complexa teia narrativa que acaba por subverter uma perspectiva meramente medicalizante. Em cena corpos, sujeitos, gêneros, dramas, agenciamentos que, apesar de atravessados pela doença, criam estratégias (est)éticas que buscam questionar as lógicas de docilizaçâo, medicalizaçâo e controle dos corpos e da vida.
\end{abstract}

PALAVRAS-CHAVE: Corpo. Gênero, saúde. Cinema. Moçambique.

ABSTRACT: By means of this article, once again, the authorial duet makes room to proliferate dialogues kin to and affected by anthropological interests. Now, the exchanges touch the importance of thinking over themes that are dear to the anthropological field, such as body, gender, and health in the light of the Mozambican cinema. For such, we focused our analysis on the short film Măe dos Netos (mother of the grandchildren). The objective, using an essay style in the writing, sought to perceive how the contemporary Mozambican cinematographic narrative signifies the HIV-Aids pandemic. Our main assumption was that the cinema in Mozambique by looking at the theme of the bodies traversed by the HIV-Aids experience constructs a dynamic and complex narrative web that ends up subverting a merely medical perspective. On the scene, bodies, subjects, genders, dramas, agency which, despite being traversed by the illness, create strategies aesthetic and ethical that seek to question the logic of docility, medicalization and control of the bodies and of life.

KEYWORDS: Body. Gender. Health. Cinema. Mozambique. 
O campo do que se convencionou chamar de antropologia do cinema tem se caracterizado como um espaço privilegiado de reflexăo no interior da Antropologia. No que diz respeito especificamente ao campo da antropologia brasileira, diversos autores têm apontado para a possibilidade da utilizaçăo de filmes como objeto de reflexáo antropológica (HIKIJI, 1998; MALUF, 2002; OLIVEIRA, 2014). Seguindo essas (des)pensaçōes e situando este trabalho em meio a esse campo de estudos, propomos o desafio de trazer a problemática do HIV/Aids nas lentes do cinema moçambicano, a partir do curta Mâe dos Netos de autoria da cineasta moçambicana Isabel Noronha, num movimento primeiro e último do cinema como multiplicador de sentidos. Nesse processo de experimentação analítica, algumas indagaçōes nos acompanharam: Afinal, como a Aids se tornou um objeto de tantos significados sócio-político-culturais, materializados nas imagens cinematográficas do cinema de Moçambique? Como o cinema nos ajuda a refletir a questăo da Aids, em Moçambique, em toda uma conjuntura histórica, ideológica, política e (est)ética?

Cabe destacar que nâo é por acaso que a temática do HIV/Aids tem ganhado a atençấo dos cineastas moçambicanos. ${ }^{1}$ Dados fornecidos pelo Instituto Nacional de Estatística de Moçambique - INE, sobre o último senso realizado no país em 2010, apontam para a importância de se pensar o impacto que a pandemia da Aids representa para aquele país. A pesquisa do INE revela a realidade dramática de um grande número de crianças infectadas pelos genitores e de órfăos deixados pela Aids. Tais aspectos săo diretamente enfocados na obra de Isabel Noronha, sobretudo no trabalho cinematográfico "Trilogia das Novas Famílias"2. Assim, a intençăo neste artigo é a de apontar para o caráter significativo e simbólico das imagens produzidas pela cineasta que, ao usar o recurso cinematográfico para retratar os "impactos" da doença no contexto cultural moçambicano, fornece pistas importantes para novas abordagens e compreensóes antropológicas de fenômenos sociais contemporâneos para além de um olhar meramente medicalizante.

Se, conforme os dados oficiais do INE, o HIV/Aids afeta 14\% da populaçăo moçambicana, certamente nâo é uma questăo a ser desconsiderada pelos cineastas locais em suas obras. ${ }^{3}$ Deste modo, se o HIV está vinculado a aspectos sócio-político-culturais complexos e as obras cinematográficas às quais tivemos acesso, como discurso, fazem parte deste cenário-enredo, acreditamos que estas produçôes, além de recolocarem para a antropologia o desafio do trabalho com imagens, também podem nos ajudar a compreender a narrativa e o imaginário da doença no contexto moçambicano. Dessa

1 Na tese de doutorado de um dos autores, buscou-se realizar o mapeamento e análise da trajetória do cinema moçambicano especialmente no que tange as produçóes voltadas para a temática do HIV/Aids (Cf. OLIVEIRA, 2014).

2 A "Trilogia" foi um documentário produzido em 2007, com 47 minutos de duraçăo, que narra três histórias de crianças e adolescentes que, com o impacto do HIV/Aids em suas famílias, tiveram que passar por novos arranjos familiares.

3 Vale ressaltar que embora este índice seja inferior aos encontrados em outros países africanos, năo deixa de ser preocupante ao ser comparado com os índices de outros países que năo chegam a alcançar o índice de 1\%. Segundo o Relatório Global da AIDS - UNAIDS (2010), a porcentagem de regióes como América do Sul e Central é de 0,5\%, América do Norte 0,5\%, Caribe 1\%, Europa Ocidental e Central 0,2\%, Oriente Médio e África Setentrional 0,2\%, África Subsaariana 5,0\%, Leste Europeu e Ásia Central 0,2\%, Sul e Sudeste da Ásia 0,3\%, Ásia Oriental > 1,0\% e Oceania 0,3\%. (Fonte: Relatório Global da AIDS, UNAIDS 2010). 
forma, contribuindo para o entendimento de aspectos e sentidos náo contemplados pelo discurso médico-institucional e que tende a encarar o fenômeno apenas (ou especialmente) sob o ponto de vista da patologizaçâo e da anormalidade. Sendo assim, năo podemos perder de vista esses diferentes aspectos que ajudam a compor a grande mise-en-scène do cinema moçambicano contemporâneo e sua relaçăo com as políticas de enfrentamento ao HIV/Aids.

Afinal, além dos altos índices de infecçâo por HIV, o que torna a Aids objeto de atençáo por parte do cinema de Moçambique? Trata-se apenas de um comprometimento político-ideológico por parte de seus cineastas com os problemas sociais de seu país ou existem outros aspectos ou razóes a serem consideradas? Tendo em vista as diversas fases pelas quais passou o cinema moçambicano e a atual dificuldade para os trabalhos de realizaçăo, sobretudo, no que diz respeito à falta de financiamento estatal, há também que se levar em conta todo o investimento financeiro, por meio de editais, de diversas organizaçóes nacionais e internacionais em torno da questăo do HIV/Aids. Tais financiamentos acabam de algum modo suprindo em alguma medida as necessidades financeiras para as realizaçôes dos cineastas moçambicanos que, diante da falta de investimento e incentivo das instituiçôes do Estado, acabam por direcionar seus trabalhos cinematográficos às demandas dessas diferentes ONGs. Em meio ou considerando as dificuldades de financiamento, há espaços para experimentaçôes est-Éticas? Eis um dos aspectos que buscamos compreender.

No trabalho de campo desenvolvido por um dos autores em Moçambique durante o doutorado, percebeu-se a grande produtividade de filmes relacionados à questăo do HIV/Aids. O que é interessante ressaltar com relaçăo aos diferentes filmes sobre a problemática e suas respectivas autorias é que, apesar das diferentes abordagens e perspectivas, há sempre uma preocupaçăo por parte dos cineastas moçambicanos com o contexto local e com o processo de compreensáo e participaçáo ativa do "Outro". Ou seja, a tentativa dos cineastas é a de tentar realizar um trabalho que seja social e politicamente relevante para a política nacional de combate ao HIV/Aids considerando os aspectos importantes da cultura local, com seus dilemas e complexidades. Assim questôes como família, parentesco, percepçăo de vida e morte, conceitos de saúde/ doença, săo permanentemente exploradas. Essa sensibilidade estética-política nâo está desvinculada do contexto sócio-político-cultural em que se inserem os cineastas, ou seja, estăo intrinsecamente vinculadas à posiçăo intelectual dos artistas moçambicanos, a sua trajetória de vida, atuaçăo política e engajamento com os rumos de seu país. Aspectos que, de algum modo, ajudaram a modelar certa noçâo de "moçambicanidade" no pós-independência e que perpassam a obra destes cineastas de um modo geral. E nesse cenário cinematográfico Isabel Noronha náo é um caso à parte no que diz respeito ao trabalho fílmico envolvendo a temática do HIV/Aids. Há outros cineastas que têm se destacado neste trabalho, como, por exemplo: Sol de Carvalho, Licínio Azevedo, Gabriel Mondlane, Camilo de Sousa, Orlando Mesquita, dentre outros (OLIVEIRA, 2014). 


\section{ISABEL NORONHA: UMA MULHER, UMA IMAGEM, UM CINEMA}

Como Isabel Helena Vieira Cordato de Noronha nasceu em Maputo, Moçambique, em 18 de Março de 1964, pode-se dizer que a cineasta é filha da "revoluçầo". Sua atuaçâo política e seu engajamento com a vida política de seu país năo deixam de imprimir marcas no desenvolvimento de sua filmografia. Algo evidenciado em sua entrevista, juntamente com Camilo de Sousa, quando da participaçâo no $6^{\circ}$ CINEPORT ocorrido em maio de 2009, na Paraíba. Acompanhemos os compartilhares de Isabel Noronha:

A minha principal expectativa é mostrar os meus filmes. E fazer com que as pessoas conheçam outra realidade e comecem a dialogar com a realidade desses outros países. Claramente, meus filmes, quase todos, săo um pouco ainda numa linha de engajamento social, porque as problemáticas de nossos países săo tăo difíceis e tăo duras, que năo faz sentido fazer cinema de outra maneira se nâo for para chamar a atençăo e para ajudar a resolver coisas que sâo urgentes e que é preciso encontrar soluçôes (NORONHA, 2016).

Observa-se no discurso de Isabel um enfoque numa experimentaçăo est-Ética em que a produçâo cinematográfica compreendida como um "falseamento da realidade" (comum às representaçóes que entendem a produçâo cinematográfica como um modo de en-cenar o mundo) cede lugar a um engajamento existencial que tem no cotidiano experienciado pela autora, a partir do contexto de seu país, um modo de afetar e ser afetado/a-perturbado/a pelas situaçôes concretas mundanas. Contudo, năo se pode confundir, a nosso ver, tal propósito com um simples ativismo-pragmático. É possível perceber no trabalho tanto da cineasta quanto de seus conterrâneos, um claro propósito de que aquilo que é mostrado sirva nâo apenas para sua transformaçăo (mera retrataçăo do mundo), mas também e principalmente para a afetaçâo/perturbaçăo (est)ética do/a expectador/a. Nesse cenário náo há espaço para a vitimizaçăo de sujeitos, realidades, práticas, por mais duros que sejam os dramas retratados. Há sim, uma disposiçăo para vislumbrar a potência da vida, o instante-já, o conatus, o fati ${ }^{5}$.

Cabe pontuar que Isabel Noronha inicia seu trabalho como cineasta ainda na juventude. É em 1984 que começa a sua atividade como cineasta no Instituto Nacional de Cinema - INC, onde inicialmente trabalha como assistente de produçâo, e onde aos poucos passa a ocupar funçôes importantes: diretora de produçâo, continuísta/ roteirista, assistente de realizaçâo e, finalmente, realizadora. ${ }^{6}$ Entre 1991 e 1997, na condiçăo de realizadora, atua como membro-fundadora da primeira cooperativa de produçâo independente de imagem em Moçambique (a COOPIMAGEM).

A experimentaçăo estética é algo marcante em suas obras, principalmente numa

4 A cineasta participou ativamente da guerra civil estabelecida no pós-independência - conflito este que se estendeu de 1977 até 1992.

5 Em nenhum momento consiste, o amor fati nietzschiano, numa doutrina do fatalismo, mas da experimentaçăo do que nos afecta e nos atravessa no devir do eterno retorno.

6 A produçâo cinematográfica de Isabel Noronha é extensa e diversificada. Destaque para alguns trabalhos: Documentário Sonhos Guardados (2004); documentário Ngwenya , o crocodilo (2007); documentário Trilogia das Novas Famílias (2008); curta Mâe dos Netos (2008); documentário Maciene, para além do Sonho (2009); filme Celeiro da Vida (2009); filme Salani (2010); documentário Meninos de parte nenhuma (2011); filme Espelho meu (2011). 
postura compreensiva face aos sujeitos filmografados. Licenciada em Psicologia, Isabel traz em seus filmes uma explícita preocupação com seus interlocutores-personagens, o que se manifesta tanto nos enquadres de sua câmera (sempre na horizontalidade) quanto no respeito que demonstra com a história de cada personagem, com sua singularidade e potencialidade ${ }^{7}$. Assim, atentar para a trajetória da cineasta moçambicana, destacando os elementos formativos e político-ideológicos ao longo de sua vida, permite que compreendamos de modo mais amplo sua obra e as características delineadas pelo seu trabalho junto aos seus interlocutores e personagens de seus filmes. Deste modo nos perguntamos, em que medida sua condiçăo de mulher num contexto profissional hegemonicamente masculino faz com que sua produçăo cinematográfica tenha um diferencial? As temáticas por ela abordadas nâo caminham de mâos dadas com este recorte de gênero, e entâo na contramăo da misoginia? E entâo seu espaço náo coincidiria com esta brecha de perspectiva e de abordagem?

De modo geral, se há trabalhos que se voltam à reflexâo sobre a condiçăo do lugar da mulher no cinema a partir de seu lócus e atuaçăo nas narrativas (interpretaçáo de papéis), pouco tem sido pensado sobre a questăo do protagonismo feminino em relaçâo à produçăo de filmes (direçâo e roteiro). Isso certamente é um dado importante, pois nos permite pensar o grau de naturalizaçâo da ideia de que na produçáo cinematográfica o gênero se dilui ou se torna coadjuvante. Pelo contrário, acreditamos que o gênero e as relaçôes que ele constitui também perpassam as produçôes cinematográficas, seja no que se refere à atuaçâo ou à produçấo. Assim, o cinema produzido por mulheres traz a potência de ruptura com regimes (est)éticos até entăo predominantes na "sétima arte", possibilitando (res)significaçôes das experiências e re-existências humanas. Movimentos que tendem a contemplar problemáticas e aspectos antes desconsiderados pelo olhar de cineastas homens e, deste modo, criando possibilidades de outros olhares, experimentaçōes e linguagens. ${ }^{8}$ Năo se trata de enfatizar eventuais visôes excludentes, antes de sublinhar o quanto o viver é um processo incrementado por fluxos de contradiçôes - também repleto de tensôes em meio às intensidades de experimentaçōes nessa travessia.

Portanto, como năo pensar esse protagonismo de cineastas feministas, que ao deslocarem o privilégio da "câmera-falo" para realidades/sujeitos/contextos abjetos, acabam por questionar a lógica da representaçáo de um Outro-distante, (re)significando o lugar de negaçăo da fala de "subalternos" para um protagonismo de uma linguagem-signo desestabilizadora da ordem antropocentrada? Nessa experiment-Açâo a "câmera-falo" perde a condiçâo de "objeto" invasor, inquiridor e violentador de um Outro exótico a ser significado, apreendido e capturado, para tornar-se um caleidoscópio de

7 Vale mencionar que os personagens presentes nos filmes de Isabel năo săo atores, mas pessoas "reais" pertencentes às comunidades onde sấo filmadas as obras e que, de modo geral, retratam a "vida como ela é". Tal modo de fazer cinema, que perpassa também a produçăo de outros cineastas moçambicanos, é intitulado de "docudrama". Esse estilo foi muito influenciado pelo neorrealismo italiano, pelo cinema novo e pela nouvelle vague.

8 Para uma reflexăo sobre as possibilidades trazidas por um cinema-feminista conferir o artigo: MULVEY, Laura. Visual Pleasure and Narrative Cinema. Screen, v. 16, n. 3, p. 6-27, Autumn 1975.

9 Aqui numa ilusăo de que haja uma (constante) negaçăo de fala aos "anormais". Antes de quaisquer negaçôes, tendemos a crer que haja uma negaçăo à escuta por parte de quem detém o acesso aos e manejo dos discursos dominantes. 
sensaçóes, experimentaçóes e trocas em que nada é previamente determinado e onde impera/opera apenas a lógica relaçăo-afetaçăo.

Assim, observa-se na escrita-cinematográfica de Isabel Noronha, um transbordamento daquilo que é retratado, um posicionamento de câmera que evidencia a criaçâo de uma horizontalidade relacional, uma equivocaçâo-estética que abre mâo de uma traduçăo totalizadora, logo-falo-cêntrica e autocentrada, tal como excerto de dizeres da cineasta acima destacados remarcam. Apropriando-nos de uma perspectiva dos equívocos (VIVEIROS DE CASTRO, 2015), diríamos que os filmes de Isabel Noronha surgem como um espaço ambíguo e descentrado onde as experiências de vida, as trajetórias e dramas dos sujeitos, suas subjetividades e relaçôes intersubjetivas săo tecidas numa malha de sentidos plurais. Nesses cenários - por mais dramáticas que sejam as histórias de vida - os dilemas sociais e os processos de violência político-social-institucional passam a ser atravessados pela afirmaçáo da potência da vida. Sob os holofotes, destacam-se e săo destacados agentes que resistem e re-existem, cujas vidas ainda mais precarizadas brotam das bordas de uma estética da existência-potência. Portanto um dos desafios que se impóe na análise de seus filmes é o de estar atento às nuances de sua narrativa e às tessituras que ajudam a compor uma parte da teia de significados que paira sobre a sociedade moçambicana, sua cultura e seus agenciamentos em torno do HIV/Aids sem cair em clivagens ou fatalismos.

Aqui a perspectiva hermenêutica geertziana quiçá dê as máos à perspectiva da experimentaçăo deleuziana. Isto porque, acreditamos que o contexto (ou com-texto) cênico dos filmes auxilia antes na experimentaçăo de alteridades radicais em nossos grupos sociais. Antes porque a intençấo năo nos parece ser a de trazer respostas às perguntas e indagaçóes que tais fenômenos/problemáticas sociais suscitam, mas de nos sensibilizarmos para a mistura que há entre o "nós-eles" que perpassa, por exemplo, a pandemia da "AIDS-SIDA". Colocar-nos à prova das sensaçôes que as películas como as de Isabel Noronha nos possibilita, é tornar a estética fílmica como uma ética da existência que nos singulariza como humanos. E entăo inter-açăo torna-se a premissa mestra, ao invés, de representaçấo.

o conhecer năo é mais um modo de representar o desconhecido, mas de interagir com ele, isto é, um modo de criar antes que um modo de contemplar, de refletir ou de comunicar (D\&G, 1991). A tarefa do conhecimento deixa de ser a de unificar o diverso sob a representaçăo, passando a ser a de "multiplicar o número de agências que povoam o mundo (Latour 1996a). Os harmônicos deleuzianos săo audíveis. Uma nova imagem do pensamento. Nomadologia. Multiculturalismo. (VIVEIROS DE CASTRO, 2015: 111-112). 


\section{MÃE DOS NETOS: QUANDO CORPO E DOENÇA SÃO ATRAVESSADOS PELO CINEMA}

Produzido em coautoria com a cineasta brasileira Vivian Altman ${ }^{10}$, o curta Mâe dos Netos narra a história de uma avó que, por causa da morte do filho e das noras (suas oito esposas), ocasionada pela Aids, se depara com o desafio de criar e cuidar de catorze netos. Financiado pela ONG - Organizaçâo Nâo Governamental - Fundaçâo para o Desenvolvimento da Comunidade (FDC), presidida pela ex-primeira dama moçambicana Graça Machel, e produzido pela Ébano Multimedia, ao qual Isabel Noronha está vinculada, o filme de 2008 tem duraçăo de 6 minutos e 50 segundos. Vale destacar que a FDC tem atuado em projetos voltados para o enfrentamento da pandemia de HIV/Aids em Moçambique, desde sua criaçáo em 1990. Mâe dos Netos convém ser compreendido tanto como continuidade das reflexóes da cineasta sobre os dilemas do HIV/Aids em seu próprio país, quanto como uma produçăo vinculada a um projeto institucional. Assim, verificar as conexóes e a rupturas entre o pessoal e o institucional também é um aspecto a ser considerado.

Com relaçâo à Mâe dos Netos, o enredo se passa numa aldeia de alguma província moçambicana e o cenário da animaçăo nos obriga a pensar na existência de outros lugares, cujas condiçóes de sobrevivência e os problemas sâo os mesmos. Utilizandose do recurso de montagem, em que mescla filme documentário com sequências de animaçăo (os personagens săo feitos de massa de modelar), Isabel e Vivian contam a história de Elisa Mabesso e de sua família. O filme inicia mostrando uma senhora sentada sobre um tapete de bambus no meio de uma aldeia, sob a sombra de uma árvore frondosa, exercendo atividades que parecem ser de seu cotidiano e, ao mesmo tempo, relatando a história e os dramas de sua família.

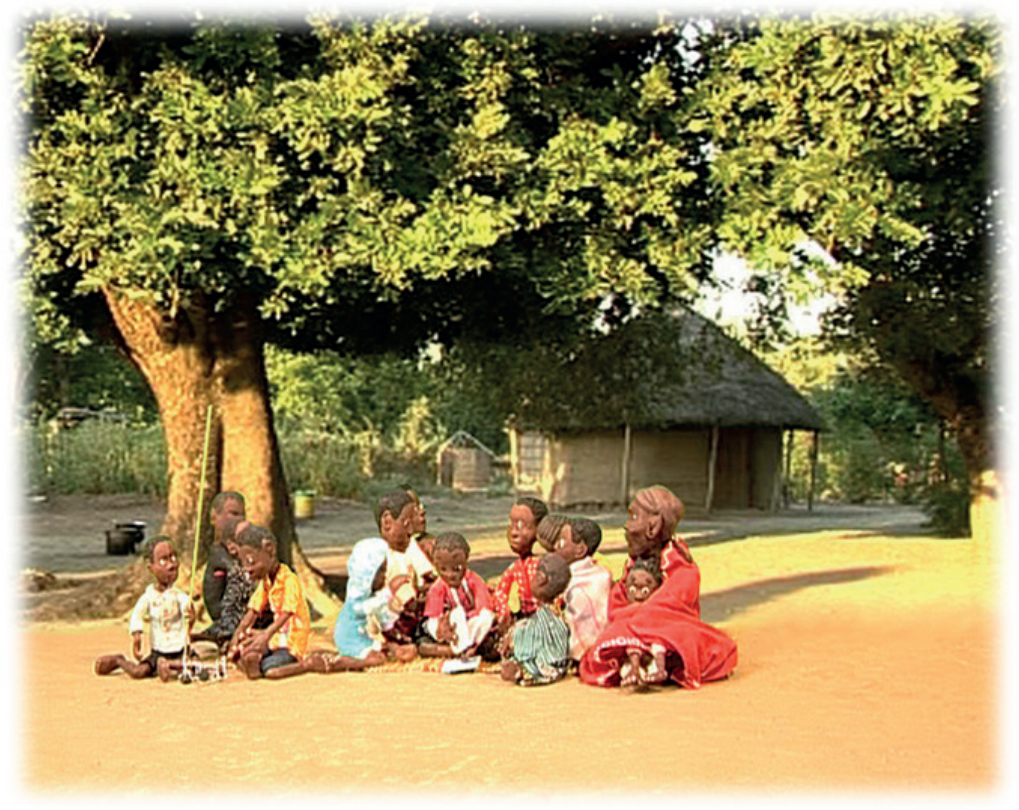

Imagem capturada do site do FICINE (2016)

10 Morando na França há décadas, Vivian Altman produz atuaçâo engajada, em especial, através do cinema de animaçăo e pela criaçăo de séries/películas com massinha voltadas aos adultos. 
A própria configuraçăo do lugar/espaço onde se desenrola a trama (ordenamento do espaço e das casas, a paisagem com uma grande concentraçáo de árvores e mata nativa, ausência de elementos que remetam a um ambiente urbano) permite inferir que se trata de uma comunidade rural, dissonante de um contexto de uma grande cidade, mas náo necessariamente excludente de estender-se a contextos urbanos.

Há toda uma mençăo ao sistema de parentesco, o que desde o início ressalta a importância da tradiçấo como aspecto de relevo na composiçăo social do grupo retratado: "Nasci na Família Muianga". Em sua narrativa a respeito das tradiçóes, a personagem compartilha que após seu casamento veio morar na aldeia Hókwé da família Muchanga, nos sugerindo a existência de um sistema de parentesco virilocal como mecanismo organizador do grupo, isto é, quando do casamento é a mulher (no casamento heteronormativo) que se muda para o lócus familiar do esposo. Após seu matrimônio, engravida e dá à luz a um primogênito: Francisco. Depois de crescido, relata a senhora Mabesso que Francisco foi para a África do Sul ${ }^{11}$, voltando depois para casar. Francisco, dentro de um sistema social em que é permitida a poligamia, casou-se com oito mulheres, resultando desses casamentos um grande número de filhos.

Em meio ao processo de compartilhamento de suas memórias, a senhora continua: “Elisa, a primeira esposa de Francisco, teve um filho - o Armando. Depois Francisco foi buscar a segunda esposa na família Mbanze, deste segundo casamento teve mais dois filhos: a Paulina e o Gustavo." Tal como a primeira esposa, a Argentina também morreu e seus filhos (Paulina e Gustavo) ficaram sob os cuidados da avó. O que parece, no primeiro momento, ser a rotina de um grupo étnico africano com seu sistema de parentesco extenso, aos poucos vai dando espaço para os dilemas vividos pela família diante da perda gradativa de seus membros em decorrência da infecçăo do HIV/aids. "O meu filho adoeceu de SIDA"12, diz a senhora. E continua: "E depois morreu."

O relato de Elisa, porém, năo para por aí. O France, o Emídio e a Mistéria, filhos da terceira esposa de Francisco (Almerinda, que também faleceu), juntaram-se ao grupo dos netos adotados de Elisa. Alegria, a quarta esposa de Francisco, também ao morrer deixou para a avó sua única filha (Vastinha). Elisa sintetiza o que acabou ocorrendo com quase todas as esposas de Francisco: "Todas as outras esposas de Francisco morreram". Tristeza, a última esposa de Francisco e que ainda năo tinha filhos, abandonou a família Muchanga após a morte do marido, deixando a velha Elisa sozinha com catorze netos. Em cena, aspectos dramáticos da situaçâo do núcleo familiar: um grande número de crianças pequenas, a idade avançada da avó, sua impossibilidade de ir para a roça (machamba) e de cuidar de todos os netos. Tudo isso expresso na preocupaçăo da debilitada avó: "Como é que eles vâo crescer?".

Ao final, o que parecia ser apenas uma "estória" de desenho animado, transforma-se em "realidade", em história de vida. Todos os personagens retratados na trama em forma de animaçáo săo substituídos por personagens de "carne e osso". A estratégia de Isabel e Vivian se elucida ao final do filme com as mensagens de conclusăo nele

11 Segundo a literatura etnográfica, é comum a migraçáo de moçambicanos para a África do Sul para trabalhar nas minas de carvấo daquele país (FIRST, 1977).

12 Síndrome da Imunodeficiência Adquirida - SIDA, no Brasil adota-se a sigla em língua inglesa (AIDS). 
inseridas: "Todas as semelhanças entre esta estória e a história da família Muchanga sáo pura realidade. Qualquer semelhança entre esta estória e a tua própria história é uma possibilidade. Para e pensa." Ali, as noçôes de "ficçăo" e "realidade" sâo reconfiguradas num jogo dialético de justaposiçấo de imagens que mimetizam e metaforizam realidades sociais complexas. Ou ainda, se misturam (re)produzindo um contínuo que torna tâo ficcional a realidade do "instante-já" quanto real a ficçâo do aqui e agora.

Num contexto marcado pelo drama da "SIDA-AIDS", o que afinal de contas implica pensar a tradiçâo conforme narrada em Mâe dos Netos? Ou a partir dela? Acreditamos que nesses dramas-contextos, a tradiçăo passa a ser reelaborada e o viver a partir do coletivo enquanto um contínuo "drama social" (na acepçăo legada ao ritual de passagem por Victor Turner), nos reporta à preciosidade da própria experiência, no sentido atribuído por Walter Benjamin (1987). Para esse, a pobreza de nossas experiências se dá, sobretudo, com o advento dos tempos modernos e com as grandes guerras/traumas, a partir dos quais năo se transmite mais conhecimento do viver, propositadamente, pela oralidade - onde a experiência é substituída pela simples vivência que năo se replica como aprendizado de experimentaçōes. O inverso ocorre na película do curta em cena nesses escritos, com o movimento da avó-mâe moçambicana partilhando experimentaçōes em forma de narrativas, por mais que advindas de traumas como da pandemia do SIDA ceifando vidas, como de Francisco e suas oito esposas. Aliás, adiante retomaremos esse mesmo evento-drama do SIDA ou "câncer gay" à luz de Michel Foucault, com seus rizomáticos atravessamentos morais que geralmente decretam mortes sociais.

(...) está claro que as açóes da experiência estáo em baixa, e isso numa geraçáo que entre 1914 e 1918 viveu uma das mais terríveis experiências da história. Talvez isso năo seja tăo estranho como parece. Na época, já se podia notar que os combatentes tinham voltado silenciosos do campo de batalha. Mais pobres em experiências comunicáveis, e náo mais ricos. Os livros de guerra que inundaram o mercado literário nos dez anos seguintes năo continham experiências transmissíveis de boca em boca. (...) Porque nunca houve experiências mais radicalmente desmoralizadas que a experiência estratégica pela guerra de trincheiras, (...), a experiência moral pelos governantes (BENJAMIN, 1987: 114-15). (Destaques nossos).

Isso nos permite pensar que, além de privilegiar a experiência-experimentaçăo por meio da narrativa, ao brincar seriamente com a noçáo de "real" e de "imaginário" ou entre "personagens de animaçăo" e "personagens de realidade", por meio da justaposiçăo documentário/animaçăo, Isabel Noronha e Vivian Altman nos apontam diretamente para a necessidade de se repensar as clivagens e as polarizaçóes travestidas de maniqueísmos redutíveis e redutores de multiplicidades. Ou ainda, os antagonismos tăo marcados-marcantes na história do Ocidente e que nas ciências sociais têm sido reiterados por meio de noçóes como: "natureza" e "cultura", "sociedade" e "grupos sociais", "humano" e "năo humano", "natural" e "artificial". Nesse sentido, somos desafiados a uma análise que nâo se abstenha de pensar os conteúdos estilísticos e semânticos das formas estéticas das imagens subversivas que questionam o estatuto ontológico-substancial de sujeitos e suas práticas. É assim que em Mâe dos Netos, os movimentos justapostos de figuraçấo dos personagens (entre animaçâo e "corporificaçăo") se entrelaçam e relativizam os modos de retratar uma dada realidade social, abrindo, assim, novas possibilidades de abordar uma problemática tăo complexa e náo convencional, 
nos provocando a pensar que entre a vida-vivida e o entendimento a priori (sem vida) de um poder que se pretende saber, há um abismo intransponível.

\section{MÃE DOS NETOS E A POLISSEMIA DO ADOECER}

Seria Mâe dos Netos um ícone de uma compreensâo do processo de saúde-doença que subverte a lógica de uma metafísica da substância? (BUTLER, 2003). Em cena corpos, sujeitos, gêneros, dramas, agenciamentos que, apesar de atravessados pela doença, criam estratégias (est)éticas que buscam questionar as lógicas de docilizaçâo, medicalizaçâo e controle da vida. Se por um lado, as organizaçôes governamentais e nâo-governamentais tem gestado desde a década de 80 diferentes campos de açăo em suas políticas de enfrentamento à epidemia de HIV/Aids, por outro, pouca atençâo tem sido dada por esses mesmos organismos ao modo como diferentes sujeitos tem operacionalizado a relaçâo saúde/prevençăo. Săo lógicas que muitas vezes mesclam-se com valores, ideologias, crenças, tradiçōes, hierarquias étnicas e de classe, etc, incluindo a pluralidade de sentidos atribuídos aos sentidos do que é doença e saúde, adoecimento, cura, tratamento, etc. Como isso é evidenciado na trama narrativa de Măe dos Netos? Trata-se de uma narrativa deslocada do tempo-espaço em que se localiza? Por outro lado, sâo vozes uníssonas? Dissonantes? Polifônicas? Nesse sentido, o que Măe dos Netos tem a dizer sobre o modo como os próprios moçambicanos lidam com o HIV/Aids e o agenciam?

Alguns autores nos ajudam a compreender a doença no contexto local (MATSINHE, 2005; PASSADOR, 2009, 2010). Em sua tese de doutorado, Cristiano Matsinhe (2005) apresenta a trajetória da doença em Moçambique desde seu surgimento (ainda na década de 80 ) e os atuais dilemas que têm caracterizado a epidemia no contexto moçambicano contemporâneo. Envolto num momento político tumultuado em que se confrontavam as duas facçôes políticas do país recém independente (FRELIMO e RENAMO), o primeiro caso de HIV/Aids (1986, em Pemba) foi, segundo Matsinhe, tratado com descaso, pois, inicialmente, o enfrentamento da doença nâo foi considerado prioritário pelas políticas oficiais (MATSINHE, 2005: 43-44). O que chama a atençâo na tese de Matsinhe sâo as situaçōes que cercam o fenômeno do HIV/Aids para além das políticas oficiais de enfretamento, e que com ele se "chocam". Ao longo da tese, o autor destaca que há uma separaçâo e um distanciamento entre as políticas de saúde e o universo cosmológico da populaçấ; as questóes de gênero que perpassam a representaçăo da doença; bem como os dilemas em torno da resistência ao uso do preservativo como mecanismo de proteçâo contra a contaminaçăo (MATSINHE, 2005: 153).

Esses conflitos, inerentes ao modo como diferentes perspectivas sâo confrontadas com relaçấo ao HIV/Aids em Moçambique, também sâo reiterados por Luiz Henrique Passador $(2009,2010)$, que apresenta como sendo uma das centralidades do "confronto" (entre o saber médico e o saber popular) o dilema entre a "modernidade" e a "tradiçăo". Segundo Passador (2009), a partir de um estudo de caso no sul de Moçambique, a própria noçấo de pessoa, conforme a compreensăo nativa, em muito destoa do modo como corpo/saúde/doença sâo abordados pelas políticas oficiais de saúde. Mas como desconsiderar o fato de que as intervençōes das ONGs e do estado obedecem à lógica das biopolíticas-biopoderes? 
Essas e outras questóes embora năo sejam evidentes no trabalho realizado por Isabel Noronha, ao serem suscitadas por meio de situaçóes metafóricas, nos proporcionam termos uma visâo mais ampla da problemática em questăo, sem que necessariamente respostas com pontos finais sejam lançadas. Assim, as diferentes situaçóes retratadas em Mâe dos Netos, dăo margem à pluralidade de sentidos que póem em suspensăo uma determinada lógica de compreensâo da epidemia e que hegemonicamente tem sido ocupada pelo discurso institucional (biomédico).

A imagem que se dá a ver através da narrativa fílmica de Isabel e Vivian é ambígua e complexa. Nầo há como nâo ser afetado/perturbado pelas imagens observadas e năo há como năo se surpreender com o desfecho da narrativa. $O$ expectador que inicialmente é induzido a sentir-pensar que se trata "apenas" de uma mera animaçâo, no final é surpreendido com a provocaçăo: trata-se de uma situaçăo real. Quem vê as cenas de Mâe dos Netos capta e cria sentidos, resgata memórias, faz associaçôes, experiencia sensaçôes. Uma operaçăo fenomenológica se estabelece a partir do olhar: "com os olhos, tocamos coisas".

$O$ ato de ver náo é o ato de uma máquina de perceber o real enquanto composto de evidências tautológicas. $O$ ato de dar a ver náo é o ato de dar evidências visíveis a pares de olhos que se apoderam unilateralmente do dom visual para se satisfazer unilateralmente com ele. Dar a ver é sempre inquietar o ver, em seu ato, em seu sujeito. Ver é sempre uma operaçáo de sujeito, portanto uma operaçáo fendida, inquieta, agitada, aberta. Entre aquele que olha e aquilo que é olhado (DIDIHUBERMAN, 1998: 77). (Destaques nossos).

Assim Mâe dos Netos nos confronta e nos questiona sobre as lógicas de significados logocêntricos que têm operacionalizado, seja a partir das políticas de saúde, seja das políticas sociais (se é que é possível estabelecer essa separaçăo!). Formas sociais de organizaçōes específicas - cosmologias, linguagens, relaçōes, cuidados de si e do Outro - sâo atravessadas e ganham "corpos" outros, bagunçando espaços em meio aos quais impera(va)m as porcentagens ou os números, conforme as estatísticas oficiais fazem questăo de reiterar e que poderíamos associar ao sujeito-massa de modelar da animaçâo-documentário, d 'onde "no fim" emergem sujeitos reais ("essa é uma história real!"). Portanto, ali se empreende uma polifonia de sentidos possíveis. As metáforas do cotidiano sâo a nós ofertadas por Isabel e Vivian como dispositivos de desnaturalizaçâo de uma "natureza morta" ou de um sujeito sem agência. Assim, diante das possibilidades interpretativas entreabertas pelas produçôes cinematográficas de Isabel Noronha, no e sobre o Moçambique atual, vislumbra-se novas estratégias locais de significaçăo e apropriaçăo de fenômenos sociais ou pelo menos apontam para os limites de uma taxonomia que tende a enquadrar tudo e todos em termos de classificaçăo e quantificaçăo.

Mas afinal, como tratar de temas tăo dramáticos, de um modo que năo leve à maior precarizaçăo de vidas já precarizadas por essência ${ }^{13}$ e por ingerência estatal? Como abordar questôes complexas sem conduzir o sujeito filmografado para o encurralamento

13 Judith Butler em diferentes momentos de sua obra adverte-nos para a obviedade de que toda e qualquer vida viva é precária desde o seu nascimento, haja vista nossa finitude corporal - "vulgo" morte. Entretanto, há pelas engrenagens estatais diferentes formas de proliferaçâo de uma maior precarizaçâo de dadas vidas em comparaçấo a outras. Eis o que se pode, inclusive, interligar à fértil discussâo sobre humanos e inumanos que também perpassa a obra de Butler, bem como seus vínculos com as discussōes nâo menos férteis sobre racismo ambiental, institucional e/ou do Estado. 
da (re)vitimizaçăo? Diferentes autores se debruçaram a pensar o documentário chamando a atençâo para tais aspectos. "Como filmar o inimigo? Como filmar um país em ruína? O que procurar para mostrar? Como filmar um campo de extermínio com milhóes de mortos sem mostrar o nada que se manifesta?", pergunta Jean Breschand (2002: 43). Como falar do grotesco, do animalesco, do visceral, sem cair num niilismo redutor? Sem anular a potência que pulsa para a vida ainda que entre escombros-ruínas? Eis o que Mâe dos Netos consegue fazer de modo crítico e sensível.

O fato é que, conforme aponta John Grierson (1998), apesar de todo o caráter político-ideológico, ainda assim a dimensâo criativa permanece sendo um aspecto fundamental da constituiçấo de um documentário, capaz de instituí-la enquanto reiteraçấo. Nesse sentido, é mais do que importante levar em conta o caráter (plural) simbólico de uma imagem fílmica para além daquilo que ela busca retratar. É necessário, portanto, a busca pela "razâo poética" (ROCHA, 1995). Afinal de contas, "as imagens por nós registradas năo serăo, elas mesmas, 'penetraçóes' no mundo que elas próprias constroem?" (ROCHA, 1995: 116). Conforme Joâo Salles (2005) devemos lembrar que a produçáo cinematográfica é, antes de tudo, um objeto desorientador que năo se define apenas por técnicas ou estilos de produçấo.

\section{CINEMA: UM MANIFESTO POR OUTRAS ANTROPO-LOGIAS/ANTRO-PÔ-LOGIAS ${ }^{14}$ ?}

Portanto, o que Mâe dos Netos nos ajuda a pensar com relaçâo às outras antropo-lógicas? Estaria o cinema um caminho alternativo-possível ${ }^{15}$ enquanto exercício epistêmico? Assim, ao nos determos sobre a imagem fílmica de Isabel e Vivian, buscamos muito menos a captura de um sentido absoluto da obra (se é que é possível, ironias à parte), do que pensar a potência que sua narrativa nos evoca com relaçáo aos sujeitos e seus agenciamentos marcados por experiências-limites. Potência visível no contínuo entre ficçăo-realidade da película em cena que desagua no transbordamento das dualidades e das fronteiras disciplinares - essa dualidade tâo cara à perspectiva que singulariza o olhar pretenso "científico". Esse borramento de fronteiras apresenta a possibilidade da implosâo das dualidades entre o "nós-eles"

14 O exercício providencial de escandir a palavra antropologia volta-se à desconstruçấo de certas obviedades. A primeira delas é do quanto alguns "conceitos" caros à antropologia - como simbólico, cultura, alteridade, pessoa - podem se tornar armadilhas, porque capturados pelo que Judith Butler (2004: 28-29) nos inspira a chamar de "violência das representaçôes". Isto é, a razâo travestida de interpretaçấo e a serviço da busca última por significados que "desvelem" quem é esse outro ou quem é esse nós no outro. Como se da interaçâo e experimentaçăo de vivências com nossos interlocutores năo houvesse espaço para o que escapa à razăo/decodificaçăo/interpretaçâo, aos moldes do que Itamar Assumpçăo compôs em "Penso, logo sinto". A outra obviedade é a de que a antropologia traz consigo o sufixo "antro", que geralmente sinaliza para significaçôes nada positivadas, como gruta que resguarda feras ou local asqueroso, porque propenso à corrupçấo ou à degeneraçâo moral. Assim, em vez de reiterarmos o lugar comum de nos atermos apenas à dualidade etimológica do "anthropos" + "logia", o que buscamos com essa escansâo é de mostrarmos o quanto a razâo tende a se tornar essa "fera" - ou mesmo essa forma impositiva de degenerarmos o outro ("nativo") - caso năo cultivemos a sensibilidade apreendida com o mínimo de aprisionamentos teóricos. Quiçá esse movimento convirja para a multiplicidade de sentidos que o agenciamento das coisas mundanas per si trazem consigo.

15 O hífen entre alternativo-possível se refere ao destaque da redundância entre ambos os termos. 
que atravessa o campo tăo delicado das moralidades que nos instituem socialmente. Dentre as moralidades aquelas que tocam a sexualidade sâo as mais evidentes, nâo apenas pelo senso comum quanto pelo discurso biomédico que o alimenta e institui estigmatizaçóes. Acreditamos ainda que, para, além disso, o poder de contestaçâo de uma obra cinematográfica ao ser produzido por sujeitos historicamente subalternizados (no caso específico, uma mulher) e voltado a pensar-sentir questóes dominadas por determinados dispositivos de saber-poder (como o saber biomédico sobre a Aids), se apresenta como potência desestabilizadora. Especificamente em relaçâo à Aids nâo podemos perder de vista que as patologias criadas-inventadas pela medicina realimentam preconceitos no seio social, e com a Aids, mundialmente isso se tornou evidente em meio à década de 1980 com os estigmas contra os homossexuais. Tanto assim o é, que a Aids ainda hoje persiste em ser veiculada em alguns contextos como "câncer gay" (SOARES, 2016). Portanto, os disciplinamentos e as vigilâncias que se imprimem sobre as sexualidades e entâo sobre o pulsar para a vida e para a vida inventiva a partir do sexo, tendem como nos esclarece Michel Foucault, a serem objetos das políticas nacionais - as biopolíticas.

Como sempre, nas relaçôes de poder, nos deparamos com fenômenos complexos que năo obedecem à forma hegeliana da dialética. $O$ domínio, a consciência de seu próprio corpo só puderam ser adquiridos pelo efeito do investimento do corpo pelo poder: a ginástica, os exercícios, o desenvolvimento muscular, a nudez, a exaltaçáo do belo corpo... tudo isto conduz ao desejo de seu próprio corpo através de um trabalho insistente, obstinado, meticuloso, que o poder exerceu sobre o corpo das crianças, dos soldados, sobre o corpo sadio. Mas, a partir do momento em que o poder produziu este efeito, como consequência direta de suas conquistas, emerge inevitavelmente a reinvindicaçáo de seu próprio corpo contra o poder, a saúde contra a economia, o prazer contra as normas morais da sexualidade, do casamento, do pudor. E, assim, o que tornava forte o poder passa a ser aquilo por que ele é atacado... 0 poder penetrou no corpo, encontra-se exposto no próprio corpo... Lembrem-se do pânico das instituiçôes do corpo social (médicos, políticos) com a ideia da uniâo livre ou do aborto... Na realidade, a impressáo de que o poder vacila é falsa, porque ele pode recuar, se deslocar, investir em outros lugares... e a batalha continua (FOUCAULT, 1979: 146).

Deste modo, o cinema apresentaria as possibilidades/potências de gestar e de parir outros discursos-práticas que nâo o da reiteraçâo do lugar de sujeitos, corpos e agenciamentos como determinados a determinados espaços, condiçôes e interdiçôes? Qual a potência disso para o campo das ciências humanas? Como diria Clarice Lispector: "Nâo se preocupe em entender, viver ultrapassa qualquer entendimento" (1998). Esse "ultrapassamento" significa estar atento às "diferentes linguagens" e ver diferentes experiências sociais como uma imagem entre outras de experimentaçăo antes de quaisquer compreensóes hermenêuticas.

Procuramos, a partir dessas questōes, estar atentos ao caráter simbólico-significativo da linguagem cinematográfica e dos signos ali apresentados. Uma imagem nunca é autoevidente, antes precisa ser compreendida no seu contexto e em relaçăo ao enredo narrativo ao qual está inserida; e isso também diz respeito tanto à imagem cinematográfica quanto à própria prática dita "científica" das áreas disciplinares. No caso do cinema, as imagens figurativas buscam transpor símbolos locais para uma linguagem global, que năo resultam numa síntese, mas numa proliferaçăo de sentidos 
polissêmicos, plurais, equívocos. Essas imagens permitem que realidades e questôes de grande complexidade nos afetem por outras perspectivas/horizontes, vieses, lógicas, a fim de que o exercício da alteridade no enlace das mais diversas relaçōes sociais se refaça/des-faça, a partir de outros lugares imaginativos. Nâo há nenhuma totalidade a ser alcançada, há apenas os sentidos possíveis e prováveis de uma afetaçâo de afectos. Numa entrevista feita com Isabel Noronha durante a pesquisa de campo de um dos autores deste artigo foi perguntado sobre a trajetória de sua produçăo cinematográfica: da construçâo do roteiro ou pré-produçâo à pós-produçăo, ao que ela respondeu: "Uma obra cinematográfica nunca é o que planejamos, se assim fosse seria tudo, menos cinema."

Talvez assim possamos compreender a proposta de David MacDougall (2009) de uma corporalidade das imagens. Para ele, antes de produzirem atos cognitivos, as imagens (fotográficas, fílmicas, artísticas) săo pura sensibilidade. Nas palavras do autor, "imagens corporais năo săo apenas imagens de nossos corpos; elas săo também imagens do corpo atrás da câmera e de suas relaçôes com o mundo" (2009: 63). Algo próximo das noçōes de "percepto" e "afecto" do autor-dual Deleuze-Guattari, expostas por Suely Rolnik (2016: 10) na entrevista "a hora da micropolítica", a partir da qual, aliás, o cinema pode e deve ser apreendido:

Um outro tipo de experiência que a subjetividade faz de seu entorno é a que designo como "fora-do-sujeito" ou "extra-pessoal": é a experiência das forças que agitam o mundo enquanto corpo vivo e que produzem efeitos em nosso corpo em sua condiçấo de vivente. Tais efeitos consistem em outra maneira de ver e de sentir aquilo que acontece em cada momento - às quais Gilles Deleuze e Félix Guattari deram o nome, respectivamente, de "percepto" (diferente de percepçăo, pois é irrepresentável) e "afecto" (diferente de afeto ou sentimento, que são emoçôes psicológicas, pois, aqui, trata-se de uma emoçăo vital que tem a ver com afectar, no sentido de tocar, contaminar, perturbar).

Lembremos que a imagem-movimento cinematográfica é instituidora de experimentaçōes estético-políticas, portanto, de po-Éticas. Como nos provoca Jacques Rancière,

Na verdade, o cinema é uma multidăo de coisas. É o lugar material onde vamos nos divertir com o espetáculo de sombras [...].É também o que se acumula e se sedimenta em nós dessas presenças à medida que sua realidade se desfaz e se altera [...]. 0 cinema é também um aparelho ideológico produtor de imagens que circulam na sociedade e nas quais esta reconhece o presente de seus tipos, o passado de sua lenda ou os futuros que imagina para si. É ainda o conceito de uma arte [...]. Mas o cinema é também uma utopia [...]. O cinema pode, enfim, ser um conceito filosófico, uma teoria do próprio movimento das coisas e do pensamento [...]. (RANCIÈRE, 2012: 14).

Deste modo, Isabel Noronha ao apresentar pelas lentes de seu cinema, um fenômeno tăo pungente e atual de sua própria sociedade, como a questáo dos impactos do HIV/Aids, coloca-nos diante das novas possibilidades compreensivas de fenômenos sociais complexos. E, ao mesmo tempo, nos desafia na elaboraçâo de novas abordagens teórico-metodológicas em meio ao pluriverso (ROLNIK, 2016 ${ }^{16}$ ) do universo dos

16 De maneira sagaz, Suely Rolnik na entrevista já referenciada nesses escritos, ao invés de usar apenas o termo universo quando está a expor a respeito do "saber-do-corpo" e as produçóes de subjetividades, 
academicismos (PINHEIRO-MACHADO, 2016). Em Mãe dos Netos, ganham "corpo" aspectos que ultrapassam em muito os sentidos medicalizantes da compreensáo da epidemia do HIV/Aids. Para além disso, a obra póe em relevo novas f(ô)rmas de abordar temáticas que historicamente săo relegadas ao plano castrador/controlador das instituiçóes ("oficiais"). E mais: trata-se de um trabalho realizado por uma cineasta, o que nos oportuniza pensarmos o papel das cineastas "mulheres" (no aspecto mais amplo e esgarçado do termo gênero) e seu protagonismo (est)ético-criativo. Portanto, por meio de um confronto que subverte a lógica de uma imagem-mundo substancial, porque dualista ou maniqueísta, Mâe dos Netos nos interpela a pensarmos-sentirmos outras antropo-lógicas através das antro(-pô)-logias. Especialmente, aquelas que nos permitam experimentarmos a compreensăo de nós mesmos e dos "Outros" que se misturam em maior ou menor medidas com nossos "nós", na contramáo dos fatalismos, (re)vitimizaçôes e essencializaçôes. 


\section{REFERÊNCIAS}

BENJAMIN, Walter. Magia e técnica, arte e política. Obras escolhidas, vol.1. Săo Paulo: Editora Brasiliense, 1987.

BRESCHAND, Jean. Le documentaire: l'autre face du Cinéma. Paris: Cahiers du Cinéma, 2002.

BUTLER, Judith. Le pouvoir des mots. Politique du performatif. Paris : Éditions Amsterdam, 2004.

BUTLER, Judith. Problemas de gênero. Rio de Janeiro: Civilizaçăo Brasileira, 2003.

DIDI-HUBERMAN, George. O que vemos, o que nos olha. Săo Paulo: Editora 34, 1998.

ECKERT, Cornélia.; ROCHA, Ana. L. C. Escrituras Hipermidiáticas e as Metamorfoses da Escrita Etnográfica no Banco de Imagens e Efeitos Visuais. Revista Iluminuras, Porto Alegre, v.7, n.16, 2006.

FIRST, Ruth. O mineiro moçambicano: um estudo sobre a exportaçăo de măo de obra. Maputo: Universidade Eduardo Mondlane/Centro de Estudos Africanos, 1977.

FOUCAULT, Michel. Microfísica do poder. 24 ed. Rio de Janeiro: Graal, 1979.

GRIERSON, John. First Principles of Documentary. In: MACDONALD, Kevin; COUSINS, Mark. Imagining Reality: the faber book of documentary. London: Faber and Faber Limited, 1998.

HIKIJI, Rose Satiko Gitirana. Imagem-Violência: Mímeses e reflexividade em alguns filmes recentes. 1998. Dissertaçăo (Mestrado em Antropologia Social), Programa de PósGraduação em Antropologia Social da Universidade de São Paulo. São Paulo: USP, 1998.

LISPECTOR, Clarice. Uma aprendizagem ou o Livro dos prazeres. Editora Rocco, 1998.

MALUF, Sônia Weidner. Corporalidade e desejo: Tudo sobre minha măe e o gênero na margem. Estudos Feministas, jan./2002. p.143-153.

MACDOUGALL, David. Significado e ser. In: BARBOSA, Andréa; CUNHA, Edgar Teodoro; HIKIJI, Rose Satiko Gitirana. Imagem-Conhecimento: Antropologia, cinema e outros diálogos. Campinas: Papirus, 2009.

MARCUS, George E. A estética contemporânea do trabalho de campo na arte e na antropologia: experiências em colaboraçăo e intervençăo. In: BARBOSA, Andréa; CUNHA, Edgar Teodoro; HIKIJI, Rose Satiko Gitirana (Orgs). Imagem-Conhecimento: Antropologia, cinema e outros diálogos. Campinas: Papirus, 2009. 
MATSINHE, Cristiano. “Tabula Rasa”: dinâmica da resposta moçambicana contra o HIV/ SIDA. 2005.Tese (Doutorado em Sociologia e Antropologia), Programa de Pós-Graduaçâo em Sociologia e Antropologia, Instituto de Filosofia e Ciências Sociais, Universidade Federal do Rio de Janeiro - UFRJ. Rio de Janeiro, 2005.

MULVEY, Laura. Visual Pleasure and Narrative Cinema. Screen, v. 16, n. 3, p. 6-27, Autumn 1975.

NORONHA, Isabel de. Entrevista no $6^{\circ}$ CINEPORT. Disponível em: https://www.youtube.com/watch?v=flalYlC2uSE. Acesso em: dez.16.

OLIVEIRA, Esmael Alves de. "Qualquer semelhança nâo é mera coincidência": uma análise do HIV/AIDS no cinema moçambicano. Tese (Doutorado em Antropologia Social), Programa de Pós-Graduaçâo em Antropologia, Centro de Filosofia e Ciências Humanas, Universidade Federal de Santa Catarina - UFSC. Florianópolis, 2014.

PASSADOR, Luiz Henrique. "Tradition", person, gender, and STD/HIV/AIDS in southern Mozambique. Cad. Saúde Pública [online]. v.25, n.3, p. 687-693, 2009.

PASSADOR, Luiz Henrique. "As mulheres săo más": pessoa, gênero e doença no sul de Moçambique. Cadernos Pagu, n.35, p.177-210, jul./dez. 2010.

PINHEIRO-MACHADO, Rosana. Precisamos falar sobre a vaidade na vida acadêmica. Disponível em: http://www.cartacapital.com.br/sociedade/precisamos-falar-sobre-a-vaidade-na-vida-academica. Acesso em: dez.16.

RANCIÈRE, Jacques. As distâncias do cinema. Rio de Janeiro: Contraponto, 2012.

ROCHA, Ana Luiza Carvalho da. Antropologia das Formas Sensíveis: Entre o Visível e o Invisível, a Floraçăo de Símbolos. Horizontes Antropológicos, Porto Alegre, ano 1, n.2, p.107-117, jul./set. 1995.

ROLNIK, Suely. A hora da micropolítica. Entrevista com. Sāo Paulo: N-1, 2016.

SALLES, Joâo Moreira. A dificuldade do documentário. In: MARTINS, José de Souza et al. (Orgs.). O imaginário e o poético nas Ciências Sociais. Bauru: Edusc, 2005.

SOARES, Luis. "Aids é câncer gay", afirma deputado pastor Marcos Feliciano. Disponível em: http://www.pragmatismopolitico.com.br/2012/09/aids-cancer-gay-deputado-pastor-feliciano.html. Acesso em: dez16.

VIVEIROS DE CASTRO, Eduardo. Metafísicas canibais: Elementos para uma antropologia pós-estrutural. São Paulo: CosacNaif, 2015. 